\title{
Mercado versus direitos humanos, de Franz Hinkelammert
}

[HINKELAMMERT, Franz. Mercado versus direitos humanos. São Paulo: Paulus, 2014, 240 p.]

Luana de Freitas Vignola ${ }^{1}$

"Os direitos do homem são muitos, e raro o direito de gozar deles"2

A citação do grande Carlos Drummond de Andrade aponta a principal razão pela qual é tão oportuno falar de direitos humanos no cenário contemporâneo. Claro, sendo os mesmos considerados um dos pilares das democracias atuais, perceber que ainda é preciso defender esta bandeira pode ser motivo de exasperação para alguns. Afinal, seria de se imaginar que, depois de tantas tragédias por sua ausência e de tantos sacrifícios para consolidá-los, a sociedade já tivesse compreendido a centralidade desses direitos. Contudo, em tempos de guerras civis, crises de fome e freqüentes ataques terroristas, sem mencionar um iminente colapso ambiental do planeta, é visível a contradição entre as previsões normativas e sua realização concreta.

E é nesse contexto que a editora Paulus publica o livro Mercado versus direitos humanos, de autoria de Franz Hinkelammert. Com uma narração em primeira pessoa demarcada pela informalidade e uma disposição de conteúdo curiosa para o gênero - são duas entrevistas

1 Acadêmica do curso de direito da UNISOCIESC - Joinville,SC e participante do Grupo de Estudo e Pesquisa Direito e Ideologias (GEPDI)

2 ANDRADE, Carlos Drummond de. O Avesso das Coisas: Aforismos. Rio de Janeiro: Record, 2007. 
e uma conferência, totalizando três partes - o livro combina economia, sociologia e teologia para realizar uma análise crítica do conflito entre o mercado e os direitos humanos.

Tal conflito é levantado por Hinkelammert logo na primeira parte do livro, a qual se contextualiza com momentos decisivos de sua trajetória de vida, que influenciaram as posições teóricas que defende até hoje. Nascido em 1932 na Alemanha, Franz Hinkelammert passou parte de sua infância e juventude no período nazista, e também estava no Chile em 1973, quando eclodiu a ditadura militar de Pinochet. Essas experiências, narradas em um formato que se assemelha a uma biografia, são utilizadas por ele na denúncia contra o terrorismo de Estado totalitário em suas afrontas aos direitos fundamentais.

Não obstante, apesar de esta crítica ter presença significativa nessa primeira parte, os horrores das ditaduras e sua doutrina de segurança nacional não são o foco do livro. Com efeito, a posição defendida pelo autor é a de que, embora a maioria dos países tenha conseguido solidificar suas democracias, a derrota do totalitarismo não significou o fim das violações aos direitos humanos. Isto porque, na visão de Hinkelammert, a humanidade ainda não conseguiu prover as condições socioeconômicas para que todas as pessoas gozem de seus direitos fundamentais, cujo acesso esbarra, assim, em dilemas práticos.

Entre esses dilemas estaria o conflito com a estrutura ideológica que acompanha o mercado e que prega a busca pelo lucro e pelo sucesso individual a qualquer custo. Essa estrutura, explica Franz Hinkelammert, ancora-se no que ele chama de razão mítica, uma construção mitológica que glorifica os valores alienados desse mercado, em detrimento de valores sociais e humanos. E, nesse processo, o autor identifica uma banalização da imagem do mundo. A visão de um lugar vibrante, complexo em toda a sua pluralidade de culturas e infinito com todas as oportunidades que a riqueza da diversidade abre, passa a ser substituído pela concepção de um mundo frio, automatizado e linear.

Mais do que isso, o que denuncia Hinkelammert é que a banalização reduz o mundo a uma máquina gigantesca da qual as pessoas e nações não passam de engrenagens, de meios para a realização de 
um objetivo - que seria a maximização dos lucros do capital. Nesse cenário, a ética e os valores que vigoram são os do próprio mercado, nos quais, de modo alheio à noção de sustentabilidade, o mais importante é maximizar a eficiência, maximizar a produtividade, maximizar tudo, em uma espiral ascendente que em tese levaria à realização pessoal absoluta e ao progresso infinito da humanidade.

Desmantelar esse mito do progresso é outro foco do livro, que aponta a periculosidade dele para os direitos humanos e para o próprio bem-estar do planeta, caso seja cultuado de forma cega e incondicionada. E Franz Hinkelammert conduz esta crítica caracterizando a ideologia que sustenta a ideia de realização pessoal absoluta como uma ideologia de competitividade, na qual vencer pressupõe derrotar o outro. A lógica apresentada, então, é a de que, se vencer pressupõe derrotar o outro, logo o progresso infinito não é para todos, pois alguém sempre perde.

E a pressuposição da derrota, aliada à visão utilitarista do mundo como um grande mecanismo de funcionamento, abriria espaço para que pessoas e nações estruturem suas relações a partir de assimetrias de poder e posições de subalternidade. Neste ponto, Hinkelammert identifica traços do que ele chama de teologia de morte, uma ideologia que, ao enaltecer o sacrifício coletivo, trata a exploração e exclusão social - a derrota - de alguns indivíduos como uma mazela inerente ao progresso - vitória - de outros.

Assim, nessa visão de mundo, condenar parte da humanidade a condições de vida deploráveis a fim de garantir riqueza para a outra parte soa inconscientemente justificável. Um cenário que, critica Hinkelammert, vai de encontro à defesa dos direitos fundamentais, já que o acesso a estes deveria ser universal, mas tem essa característica comprometida quando os valores da sociedade se tornam mais utilitaristas do que humanos.

É nesse contexto que o autor realiza uma das críticas mais marcantes do livro, ao afirmar que o indispensável tem se tornado inútil. Tal afirmação aparenta ser paradoxal, mas encontra seu sentido no fato de que, na lógica da exploração indiscriminada, a defesa dos valores 
intrínsecos à humanidade e do cuidado com o planeta visando à sua sustentabilidade futura - ações indispensáveis - são consideradas inúteis porque não geram tanto lucro quanto seu oposto. Desta maneira, prevalece uma ideologia mecanizada, que abre as fronteiras para o capital, mas não para refugiados de guerra, que defende os direitos humanos, mas falha em prover condições materiais para que todos possam gozar deles.

Com essa crítica, chega a advertência final de Franz Hinkelammert: a insustentabilidade desse modelo a longo prazo, diante da crise humana que ele acarreta e de uma rebelião dos limites do planeta, incapaz de sustentar o ritmo da busca interminável pelo lucro sem comprometer o futuro das próximas gerações. Nesse sentido, é evidente, enfim, uma posição pessimista do autor com relação aos rumos da humanidade e à possibilidade atual de corrigi-los e assegurar a todas as pessoas uma existência digna.

Todavia, o mesmo caracteriza essa posição como um "pessimismo com esperança", que, embora se mostre cético à probabilidade de solucionar todas as mazelas do planeta, não a descarta por completo, mantendo uma perspectiva de que, por meio de ações que conciliem o individual com o coletivo e busquem uma ética de convivência, esse objetivo ainda seja possível. Desta maneira, prevalece no livro uma abordagem crítica da realidade, que denuncia as problemáticas contemporâneas mais latentes, porém sem deixar de apontar uma visão de como acredita que o mundo deveria ser - um lugar não tão mecânico e frio, no qual os direitos humanos não sejam apenas muitos, mas também concretamente assegurados e efetivamente usufruídos por todos. 